\title{
THE ANALYSIS OF DISUSED RAILWAY LINES AS COMPLEX SYSTEMS: GIS-BASED INVENTORY AND COMPREHENSIVE ANALYSIS METHOD
}

\author{
A. EIZAGUIRRE-IRIBAR, L. ETXEPARE IGIÑIZ \& R.J. HERNÁNDEZ-MINGUILLÓN \\ Department of Architecture, University of the Basque Country UPV/EHU, Spain.
}

\begin{abstract}
Many kilometres of railway lines are disused in territories where the railways had been dependent on industrial development. The current broad concept of heritage and its territorial character make the proposition of these lines as territorial structuring systems possible. Nevertheless, most of the actions for their protection, restoration or enhancement are fulfiled in some isolated elements, not attempting to understand the line as a territorial system that is formed not only by the nodes but also by the connecting thread. Furthermore, the passage of time and the lack of use have made many heritage elements be in danger of disappearing, if not already disappeared. In this regard, this article emphasizes that the analysis of the disused railway lines should be performed with a comprehensive vision in order to achieve the same results for their protection or for future interventions. This paper aims to create a GIS-based inventory and a comprehensive analysis method for the characterization and classification of disused railway lines of a territory, understanding them as complex systems. The way to address the issue is to avoid the decomposition of the system and favour the maintenance of the structuring nature that the railway lines originally had in each territory, which is one of the most important features for their possible reuse in the new territorial view of the 21 st century. In this way, the proposed methodology has been applied on the disused railway lines of the Basque-Navarre territory.

Keywords: comprehensive method, disused railway lines, GIS-based inventory, railway heritage.
\end{abstract}

\section{INTRODUCTION}

The closure of many kilometres of railway lines was induced throughout the second half of the 20th century due to the competition from road transport as well as from industry decline. The railway was closely linked to industrialization and subsequent urban development in its arrival, so it was actively involved in the profound changes that were occurring in cities [1]. What is more, it was linked to the structuring of the surrounding territory as well as organizing it hierarchically. It had a selective power to choose some areas and exclude others [1], thereby affecting territorial evolution. Their closure should be understood as a turning point in this territorial evolution and as an excellent starting point for a next stage. These disused railway lines set a railway heritage of great interest, but some problems for the creation of future possible strategies have been identified.

The first problem is that the lack of use and passage of time have made railway heritage to be in danger of disappearing. The inherited railway heritage has been adapting to the new needs of railway and even to new uses after their closure. The lack of use endangers this heritage because it accelerates the deterioration process considerably. This factor makes it difficult to have constantly updated information, which in turn is essential to create new strategies and ensure the future of that heritage.

The second problem is the observed mismatch between theoretical and practical achievements. The concept of heritage has been extended from monuments to cultural and natural heritage in the past decades [2], which has led to the emergence of new categories that engulf a broader nature. Although the promotion of the railway heritage is still at an early stage, this 
heritage has been already recognized as a cultural heritage and it is linked to other subtypes of heritage, such as industrial or public works. This has helped to understand the railway heritage in its entirety. In addition, industrial railway heritage assets are classified into different groups as movable assets, real estate, facilities or infrastructure of the road [3]. Thus, a system in which the value comes from the existence of a structured set with global significance is formed [4] and the principal value of its set of components is being an integral part of a whole [5]. Furthermore, railway heritage is directly related to the surrounding territory and landscape. Disused railway lines are in constant interaction with their environment. That is why, nowadays, they are part of the concept of the cultural landscape defined by UNESCO in 2008 [6] or the cultural route defined by ICOMOS in 2008 [7].

Although the broad concept of heritage and its territorial character pave clear steps for a comprehensive vision of the theoretical understanding of this heritage, an integrated and cross-cutting management should also be involved. In this regard, a mismatch between theoretical and practical achievements demonstrates the difficulty to apply this integrated view [4]. Indeed, the actions taken for their protection, restoration and enhancement, are fulfiled in some isolated elements losing the system nature they once had.

On the one hand, there have been initiatives to protect these systems with a comprehensive vision. Some examples are the protection as 'industrial landscape' proposed in the Basque Country [8] or the existence of the legal figure of 'industrial landscape' in Navarre [9], both in Spain. But in practice, the legally protected items are isolated elements and their figures have a limited scale. On the other hand, restoration and enhancement interventions are generally focused on isolated elements and buildings (nodes) or on the line, but not on the whole. Interventions in nodes mainly focus on the rehabilitation of stations and their environments, and they may be carried out by the councils of each municipality or specialized associations. In spite of the work of documentation, protection and restoration that they have developed, each element is considered in isolation and with varied uses, which may lead to the fragmentation of the system. Interventions in line or path have specially focused on their reuse as non-motorised transport infrastructures (Greenways or Rail-Trails). The restoration of the built railway heritage is proposed as part of them, although in practice this type of intervention focuses on a single node.

This paper argues that approaches regarding the protection of disused railway lines could go a step forward by means of an integrated enhancement that is able to take advantage of the potential of the whole system. The literature offers some theoretical approaches, such as the methodology for the analysis of disused railway lines as complex systems [10], in which this paper is based, or the guidelines for putting in value stations and other built railway heritage as a whole [11].

Taking all these into account, this article emphasizes that the analysis of the disused railway lines should have a comprehensive vision in order to achieve the same results for their protection or for future interventions. The constant updating of data is considered essential for this achievement. In this regard, this paper aims to create a GIS (Geographic Information System)-based inventory and a comprehensive analysis method for the characterization and classification of disused railway lines of a territory, understanding them as complex systems. This conception enables keeping the structuring nature they once had in the territory. This is one of the most important features for their possible reuse and influence in the development of their environment, again making the proposition of these lines as territorial structuring systems possible. 


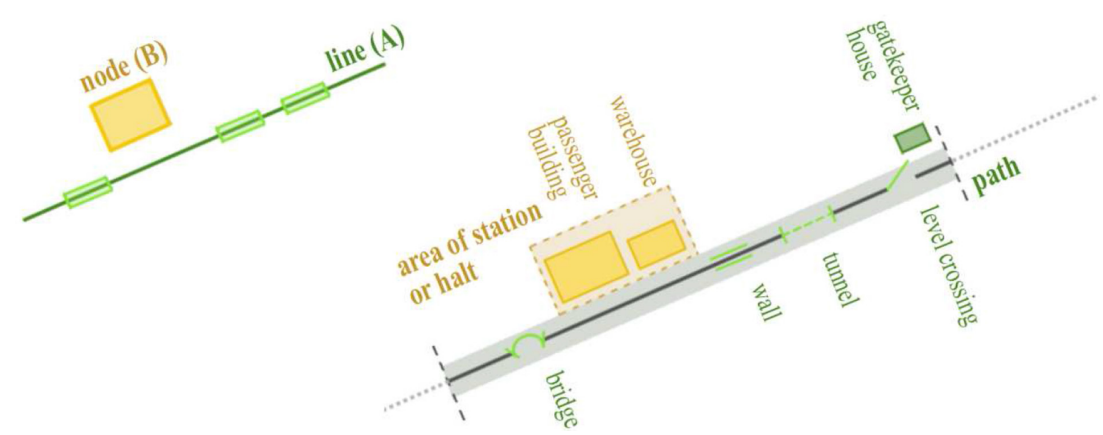

Figure 1: The two components of a railway system (left) and their elements (right).

\section{THE DISUSED RAILWAY SYSTEM (DRS)}

The concept of disused railway system (DRS) has been already defined in literature [10]. As a background, it is necessary to understand that a system is characterized by their elements or parts as well as the interactions between them, each part being based on another [12]. In this regard, a railway is a territorial system, formed not only by the nodes but also by the connecting thread, Fig. 1. The connecting thread is the path, which creates longitudinal flows in the territory, and consists of a linear infrastructure and all specific elements that make it possible. Meanwhile, the nodes are the areas of stations or halts that create the connection between the rail line and the territory, and can be formed either by a simple shelter or by a set of buildings. The railway is a complex system that has acted as a structuring element of the territory when it arrived. It had a favourable influence area around, which was served by the train, excluding territories through which the train did not pass, thereby creating a territorial hierarchy. The nodes in turn created a second hierarchy within the system. In this way, railways and their stations became integrated with the axis of the city and society, into the hubs of the economic, social and cultural activities [13].

Disused railway lines are also understood as territorial systems composed of their nodes and connecting thread. Consequently, the set of built railway heritage acts as part of the system, where the line gives meaning to all elements, its connecting ability being the most favourable feature to consider [11]. In this case, the relation between the system and the territory is limited not just to the existing nodes, because any external element could work as a node due to the variety of possible future uses of the system.

\section{METHODOLOGY: INVENTORY AND COMPREHENSIVE ANALYSIS}

The analysis of disused railway lines as complex systems is proposed in this paper. In this regard, an inventory and a comprehensive analysis of each system provide the characterization of each disused line, Fig. 2. On the one hand, a GIS-based inventory facilitates a correct data structuration and a continuously actualised data set, in order to know the current state of the heritage. On the other hand, a comprehensive analysis, based on the previous definition of DRS, results in the potential of territorial structuring of the analyzed system. Furthermore, the study of the different DRSs of a certain territory makes it possible to create a classification of these systems, Fig. 2. 


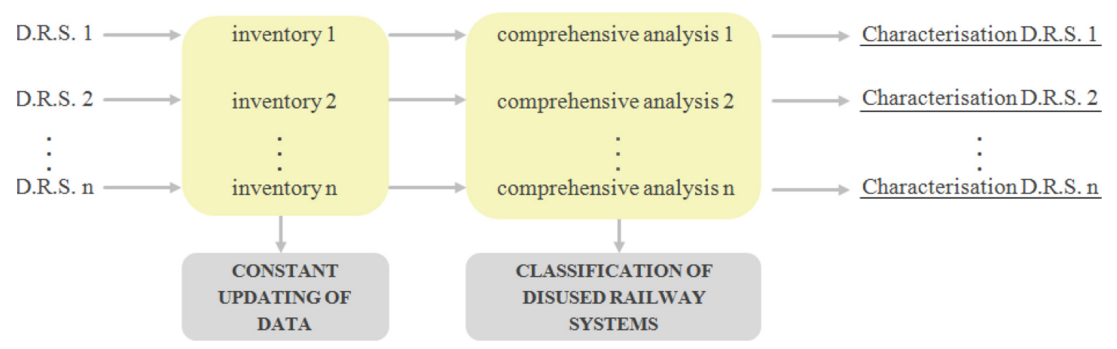

Figure 2: Methodology diagram for the analysis of DRSs.

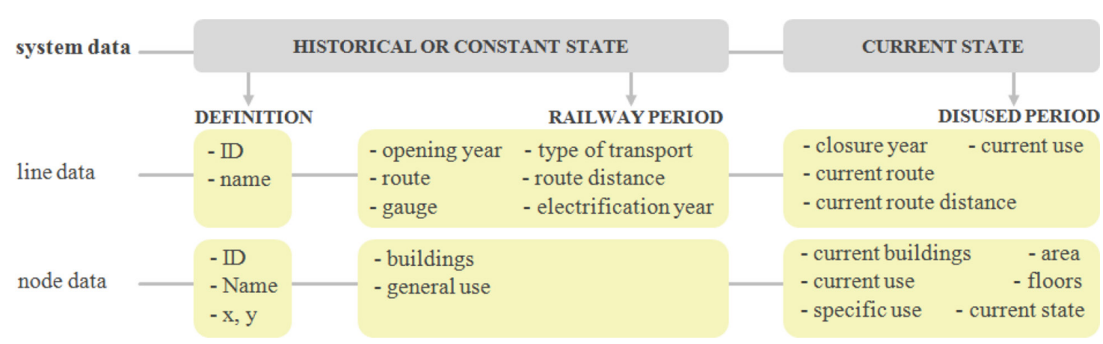

Figure 3: Information required for the GIS- based inventory.

\subsection{GIS-based inventory of railway heritage}

Due to the continuous damage and disappearance of the heritage elements of the systems, a GIS software is selected because it permits easy data storage, management and updating. The GIS-based inventory could provide large amount of high-quality, georeferenced and constantly updating data, in order to obtain information of different periods. Historical data related to the period in which the railways were in use and their current status are required for the analysis proposed below.

The information of each system is structured according to its components, i.e. according to the data referred to the line and the nodes. Two types of shapefiles are created in order to define each disused railway line (system): a linear shapelife (path) and a point shapefile (nodes). Figure 3 shows the selected information for each period and type of shapefile. The inventory should be detailed according to the selected analysis scale. The analysis of different systems, as in this case, requires data that must be comparable, so few specific data should be selected. In addition to the inventory referred to all the systems, the data related to territory is compiled for the comprehensive analysis. As mentioned in the introduction, railway heritage is directly related to its surrounding territory, generating relationss between them. Thus, a polygon shapefile with municipal boundaries is created to represent the surrounding territorial data. The required attribute table of these shapefile is defined with the following characteristics: ID; Name; Area; Population (beginning of the railway activity); Population (closure of the railway activity); Current population. Finally, other shapefiles are used to represent towns and rural communities, rivers, protected natural areas or main infrastructures. 


\subsection{Comprehensive analysis method}

Taking into consideration the previous definition given for the concept of a system, the comprehensive analysis covers both component elements and their relations, dividing the analysis into four different areas. As a result, the characterization of each selected disused railway line is obtained, with the aim of creating a classification of different systems with reference to their capability to work as a structuring element in the territory. The higher the capability, the wider the range of future strategies that the line can include for a new use.

Two variables are obtained in each analysis area. One of them refers to the historical or constant state of the system, whereas the other refers to the current state. Depending on the combination of the range of these variables, the system will be classified into one of the five categories related to its territorial structuring capability, Fig. 4. 1, 2 and 3 represent a real capability, whereas 4 and 5 represent a future possible capability. This is because it is considered that the historical analysis provides interesting data, especially in cases where the current analysis results are less favourable. A system with a high territorial structuration or integration in its historical status enables the recovery of this system with same characteristics.

The proposed comprehensive analysis is performed in four areas: the line, the nodes, the relations between the system elements (internal) and the relations between the system and the surrounding territory (external).

On the one hand, the elements involved in the system are analyzed, without taking into account the relations they have with other elements or their environment. In a railway system, the main elements are two: the line and the nodes. Related to the line (A in Fig. 5), data such as track gauge or type of transport can be very characteristic to understand the evolution or the closure of a railroad. Nevertheless, the level of preservation of the line is considered as the main factor to define the system and its possible recovery of the structuring effect on the territory. Therefore, the percentage of preserved line and the current state are measured. The last one consists of the state of preservation (ruin, poor, regular or good), its general use and the reversibility of the disappeared sections. In reference to the nodes (B in Fig. 5), the collected data allows an easy measurement of the preservation level of built heritage, as well as the characterization of each system. The higher the level of preservation, the greater the possibilities for system recovery, assuming different types of uses. The percentage of preserved elements or items is the first variable, whereas their current state is the second. Three indicators are defined for this second variable: state of preservation (ruin, poor, regular or good), percentage of disused items and percentage of items with public use.

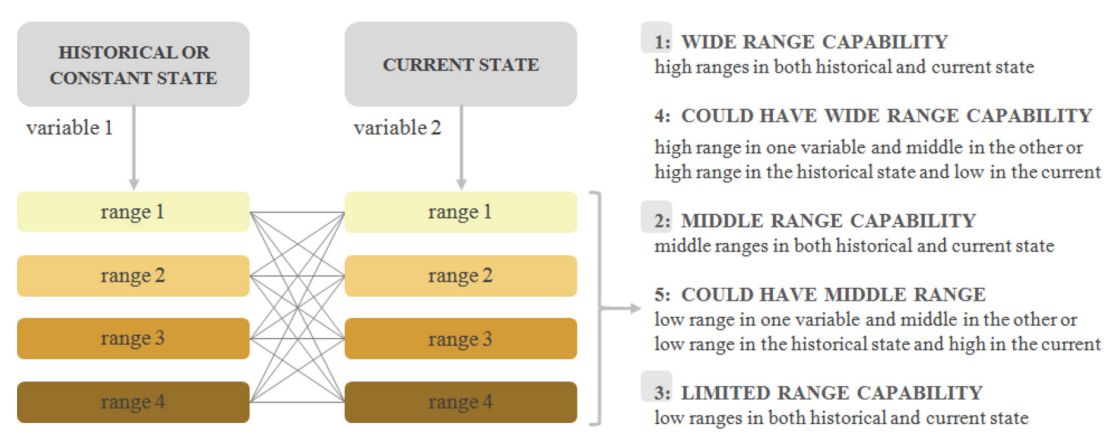

Figure 4: Different ranges of the two variables and the resulted categories. 


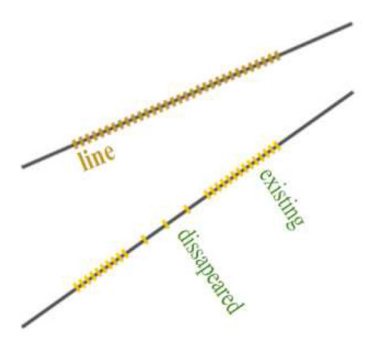

line (A)

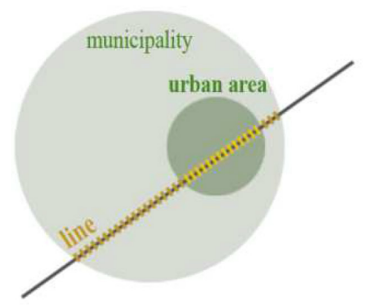

line/territory (D)

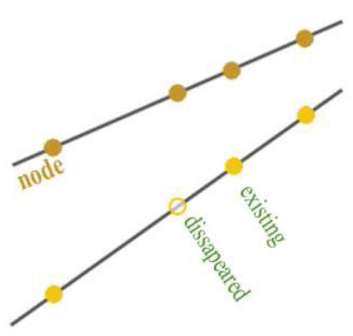

nodes (B)

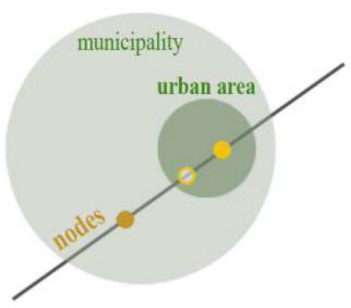

node/territory (E)

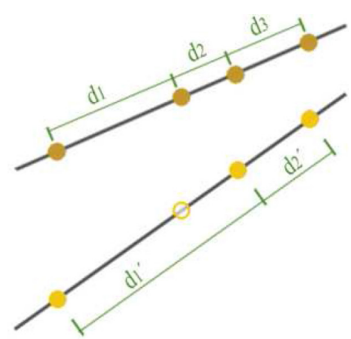

line/nodes (C)

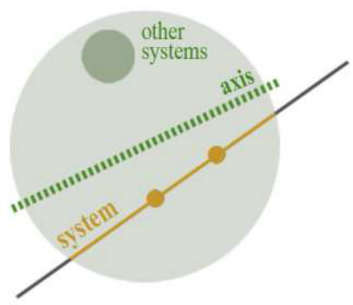

system/territory (F)

Figure 5: Components and created relations in a DRS.

On the other hand, the relations existing between the system elements and that created between the system and the surrounding territory are analyzed, thus defining two types of relations. The relations created between the system elements are called internal relations, in this case, those created between the line and the nodes ( $\mathrm{C}$ in Fig. 5). The first variable, concerning the historical state of the line, is deduced from the distances between the nodes, considering both all nodes and only those which comprised any building. The second variable is inferred by the distances between existing nodes and the length of the line in relation to the floor area of the existing buildings. The relations created between the system or its elements and the surrounding environment are called external relations. In this case, the line, the nodes and the whole system are related to the territory. First, in 'line/territory' relations (D in Fig. 5), the population and the municipal surface area concerning the line are analyzed for the historical state, while the population, the municipal surface area and the number of towns and rural communities related to the line are studied for the current state. Secondly, in 'node/territory' relations (E in Fig. 5), the population and the municipal surface area regarding the number of nodes and buildings are analyzed for the historical state, while the population and the municipal surface area related to the number of nodes and their surfaces areas are studied for the current state. Thirdly, in 'system/territory' relations (F in Fig. 5), the existence of rivers or mountains crossing the line is observed for the historical or constant state. For the current state, two indicators are analyzed: 1) the existence of protected natural areas and 2) the existence of current or future elements for the strengthening of the line axis.

Finally, the uniformity of the system is checked because the analysis conducted focuses on the mean values for each data and a further examination may allow a more accurate approximation. The construction of box-plot type graphs, from data of relations between nodes and line, allows deciding whereas a division of the analyzed systems into zones is necessary. One reason for the division could be that line sections with very different characteristics exist within the same system, due to an unequal distribution of the nodes or specific territorial characteristics. 
The interquartile range or the existence of outliers of such graphs will be considered for this. If a division is necessary, the analysis will be carried out again for each divided section.

The results for each part of the analysis (A, B, C, D, E, F) will be represented in the previously defined categories $(1,4,2,5,3)$, by measuring the capability of territorial structuring of the system and obtaining the characterization of each DRL.

\subsection{Classification of DRLs}

As a final step, PCA (Principal Component Analysis) and k-mean classification are used to compare and classify the different systems in order to design future common strategies for their promotion. The PCA is parameterized using Pearson correlation with a significance level at $95 \%$ applied at the initial matrix. The principal components, the contribution of each variable and the coordinates of components for each DRL are obtained. The k-mean classification is employed with 500 iterations and a convergence value of 0.00001 . The data is tested with the coordinates of the first three component axes obtained from the PCA.

\section{STUDY AREA AND DATA: INVENTORY OF THE BASQUE-NAVARRE DRSS}

The main disused railway lines of the Basque Country and Navarre (Spain) have been selected for the application of the proposed methodology. The Basque Country is the territory with the highest percentage of kilometres of disused railway lines per $\mathrm{km}^{2}$ in the state [14]. The closure of the last line was in 1987 and, hence, the current deterioration of most of the assets begins to rise considerably. In the study, twelve lines that were used for the transport of goods and passengers have been selected. They are the ones that may have some potential in the regional planning of their surrounding areas.

The inventory of the Basque-Navarre DRSs has been developed by means of data collection and fieldwork performed. On the one hand, the railway heritage of the Basque Country and Navarre has been identified and inventoried in a GIS software, providing us constantly updating data. On the other hand, the creation of different maps and analyses in GIS is possible, such as the analysis of the historical development of the system or the preservation state of the nodes, in order to understand these lines as complex systems.

The inventory comprises several systems and each system includes the line and multiple nodes, Fig. 6. In this case, 12 lines and 217 nodes have been identified and analyzed in total. All these data have been structured depending on the periods mentioned before (definition, railway period, disused period). Otherwise, the data concerning the territory are obtained from the spatial data infrastructures of each territory (Basque Country: geo.euskadi.net; Navarre: idena.navarra.es). Historical and current demographic data are also included from the Basque Statistics Institute (Eustat), the Statistical Institute of Navarre and the National Institute of Statistics, INE. In this study, the demographic data of 1930 and 1981 were compiled for the historical state. In the first date, all selected lines had been already constructed, whereas in the second, all of them had been closed or were on the verge of it.

\section{RESULTS: CHARACTERIZATION AND CLASSIFICATION OF DRLS}

\subsection{Comprehensive analysis of the Basque-Navarre DRSs}

The analysis has been applied in the six mentioned parts (A, B, C, D, E, F) of each system, taking into account both component elements and their relations. The part of the analysis 


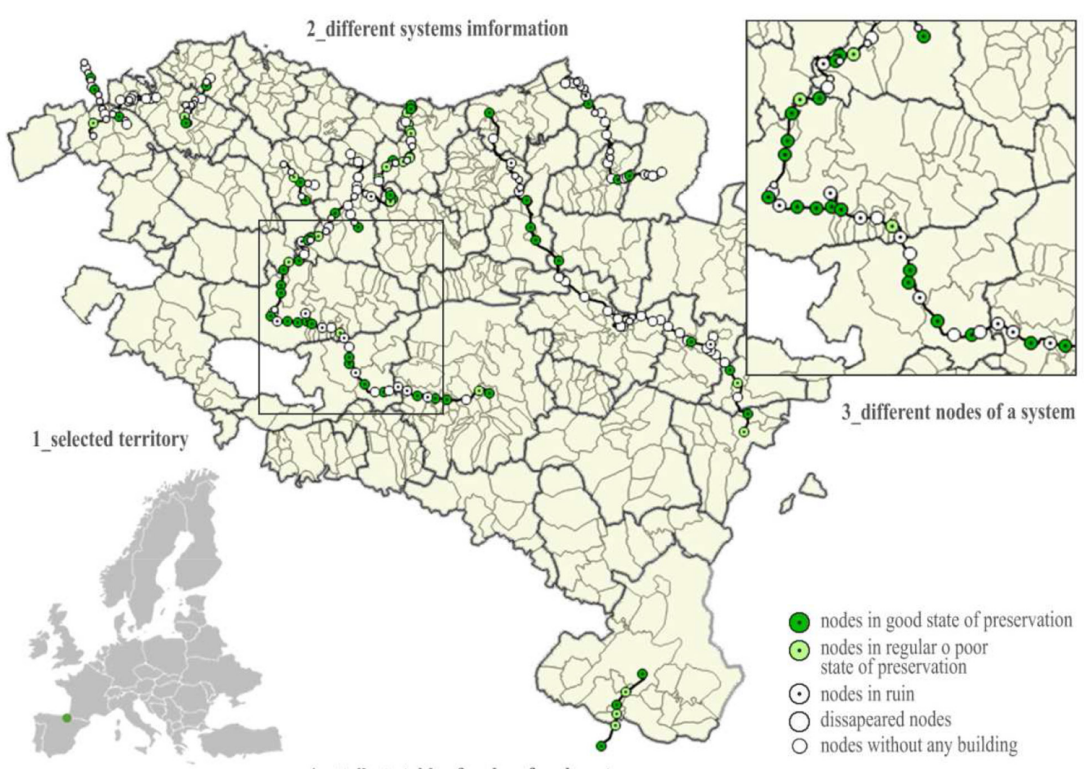

4 attribute table of nodes of each system

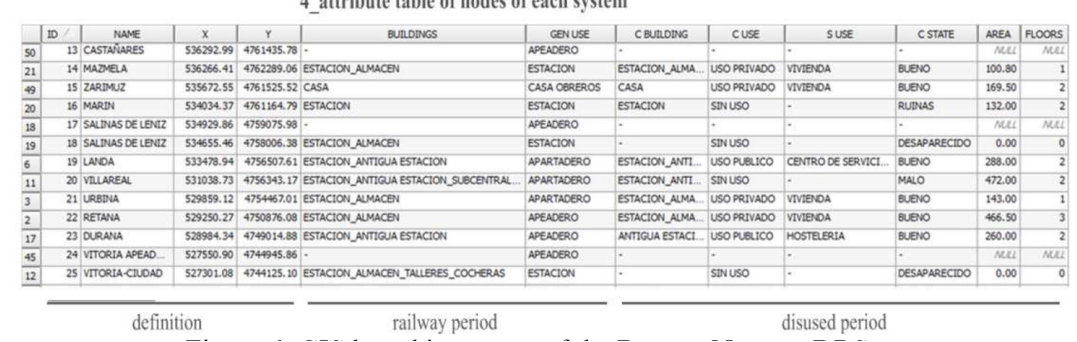

Figure 6: GIS-based inventory of the Basque-Navarre DRSs.

referred to the line (A) has been neglected due to the similarities in the results. Nowadays, all selected lines have similar gauge (narrow gauge) or current use (greenway or cycle lane). That is why the paths remain at a high proportion although some kilometres have disappeared.

In the analysis related to the nodes (B), the presented two variables (see section 3.2) have been obtained from collected data and divided into four ranges, Table 1 . The first variable refers to the percentage of nodes preserved, while the second refers to their current state of preservation. Depending on the combination of these variables, the disused railway lines are categorized in the previously presented five categories, which represent the capability range of the territorial structuring of the system ( $\mathrm{B}$ in Table 2). The data referred to line/node analysis (C) is also shown and categorized in Table 1 . The same categorization has been applied for the created external relations (D, E and F) of the studied lines and the results for each study area are shown in Table 2.

The main conclusions of the analysis have been obtained once the comprehensive method has been carried out. On the one hand, Urola railway has the best results because it was the last to close and it preserves almost all its nodes. This means that it has a high territorial structuring potential, in order to cover new uses beyond the current greenways. On the other 
Table 1: Data referred to the node analysis (B) and line/node analysis (C), both ranged in 4 levels.

\begin{tabular}{|c|c|c|c|c|c|c|c|}
\hline \multirow{2}{*}{$\begin{array}{l}\text { NODE } \\
\text { ANALYSIS (B) }\end{array}$} & \multirow{2}{*}{$\begin{array}{l}\text { existing } \\
\text { nodes } \%\end{array}$} & \multicolumn{4}{|c|}{ state of preservation $\%$} & \multirow{2}{*}{$\begin{array}{c}\text { disused } \\
\% \text { of } \\
\text { existing }\end{array}$} & \multirow{2}{*}{$\begin{array}{l}\text { public use } \\
\% \text { of in use }\end{array}$} \\
\hline & & ruin & poor & \multirow{2}{*}{$\frac{\text { regular }}{25.00}$} & \multirow{2}{*}{$\frac{\text { good }}{43.75}$} & & \\
\hline Urola & 84.21 & 0.00 & 31.25 & & & 56.25 & 71.43 \\
\hline Maltzaga-Zumarraga & 16.67 & 100.00 & 0.00 & 0.00 & 0.00 & 100.00 & 0.00 \\
\hline Vasco-Navarro & 73.33 & 24.24 & 9.09 & 3.03 & 63.64 & 33.33 & 54.55 \\
\hline Durango-Elorrio & 66.67 & 0.00 & 0.00 & 0.00 & 100.00 & 0.00 & 100.00 \\
\hline Plazaola & 50.00 & 28.57 & 0.00 & 0.00 & 71.43 & 28.57 & 60.00 \\
\hline Tudela-Tarazona & 100.00 & 0.00 & 16.67 & 33.33 & 50.00 & 50.00 & 66.67 \\
\hline Traslaviña-Castro & 55.56 & 20.00 & 0.00 & 20.00 & 60.00 & 20.00 & 50.00 \\
\hline Sestao-Galdames & 20.00 & 0.00 & 0.00 & 50.00 & 50.00 & 0.00 & 100.00 \\
\hline Sondika-Mungia & 33.33 & 0.00 & 0.00 & 0.00 & 100.00 & 100.00 & 0.00 \\
\hline Bilbao-Lezama & 100.00 & 0.00 & 0.00 & 0.00 & 100.00 & 0.00 & 100.00 \\
\hline Irati & 31.58 & 16.67 & 0.00 & 33.33 & 50.00 & 16.67 & 0.00 \\
\hline \multirow[t]{6}{*}{ Bidasoa } & 23.81 & 20.00 & 0.00 & 0.00 & 80.00 & 20.00 & 0.00 \\
\hline & \multicolumn{3}{|c|}{$\begin{array}{c}\text { VARIABLE } 1 \text { HISTORICAL } \\
\text { OR CONSTANT STATE }\end{array}$} & & \multicolumn{3}{|c|}{$\begin{array}{c}\text { VARIABLE } 2 \\
\text { CURRENT STATE }\end{array}$} \\
\hline & \multicolumn{3}{|c|}{ range 1} & & \multicolumn{3}{|c|}{ range 1} \\
\hline & \multicolumn{3}{|c|}{ range 2} & & \multicolumn{3}{|c|}{ range 2} \\
\hline & \multicolumn{3}{|c|}{ range 3} & & \multicolumn{3}{|c|}{ range 3} \\
\hline & & nge 4 & & & & range 4 & \\
\hline $\begin{array}{l}\text { NODE/LINE } \\
\text { ANALYSIS (C) }\end{array}$ & $\begin{array}{l}\text { nodes per } \\
\text { line } \mathrm{km}\end{array}$ & & $\begin{array}{l}\text { uildings } \\
\text { line } \mathrm{km}\end{array}$ & & $\begin{array}{l}\text { buildings } \\
\text { er line } \mathrm{kn}\end{array}$ & flo & $\begin{array}{l}\text { oor surface } \\
\text { er line } \mathrm{km}\end{array}$ \\
\hline Urola & 0.68 & & 0.52 & & 0.44 & & 244.12 \\
\hline Maltzaga-Zumarraga & 0.27 & & 0.23 & & 0.04 & & 3.68 \\
\hline Vasco-Navarro & 0.39 & & 0.33 & & 0.24 & & 87.67 \\
\hline Durango-Elorrio & 0.46 & & 0.20 & & 0.13 & & 37.22 \\
\hline Plazaola & 0.21 & & 0.17 & & 0.08 & & 34.52 \\
\hline Tudela-Tarazona & 0.27 & & 0.27 & & 0.27 & & 257.27 \\
\hline Traslaviña-Castro & 0.58 & & 0.29 & & 0.16 & & 34.63 \\
\hline Sestao-Galdames & 0.62 & & 0.44 & & 0.09 & & 24.00 \\
\hline Sondika-Mungia & 0.82 & & 0.25 & & 0.08 & & 9.71 \\
\hline Bilbao-Lezama & 0.47 & & 0.09 & & 0.09 & & 92.55 \\
\hline Irati & 0.41 & & 0.33 & & 0.10 & & 33.57 \\
\hline Bidasoa & 0.62 & & 0.41 & & 0.10 & & 19.81 \\
\hline
\end{tabular}


Table 2: Results for each analyzed area of the comprehensive analysis method.

\begin{tabular}{llllllllllllll}
\hline & & B & C & D & E & F & & B & C & D & E & F \\
\cline { 2 - 13 } & Urola & 1 & 1 & 2 & 1 & 1 & U1 & 1 & 1 & 2 & 1 & 1 \\
1: wide range & Maltzaga-Zumarraga & 3 & 3 & 2 & 3 & 2 & U2 & 4 & 1 & 1 & 2 & 1 \\
capability (c.) & Vasco-Navarro & 2 & 2 & 2 & 2 & 2 & VN1 & 4 & 2 & 2 & 3 & 1 \\
4: can have a & Durango-Elorrio & 1 & 2 & 2 & 2 & 1 & VN2 & 2 & 3 & 2 & 2 & 3 \\
wide range c. & Plazaola & 2 & 3 & 2 & 3 & 1 & VN3 & 1 & 2 & 2 & 3 & 2 \\
2: middle & Tudela-Tarazona & 1 & 4 & 2 & 5 & 5 & VN4 & 2 & 4 & 3 & 2 & 4 \\
range c. & Traslaviña-Castro & 2 & 2 & 2 & 4 & 5 & VN5 & 1 & 4 & 3 & 1 & 4 \\
5: can have a & Sestao-Galdames & 5 & 5 & 1 & 3 & 5 & I1 & 3 & 3 & 2 & 3 & 5 \\
middle range c. & Sondika-Mungia & 2 & 5 & 2 & 5 & 2 & I2 & 2 & 2 & 3 & 2 & 4 \\
3: limited & Bilbao-Lezama & 1 & 2 & 2 & 3 & 3 & B1 & 3 & 4 & 1 & 2 & 1 \\
range c. & Irati & 2 & 2 & 2 & 3 & 4 & B2 & 3 & 3 & 2 & 5 & 1 \\
& Bidasoa & 5 & 5 & 3 & 2 & 1 & B3 & 2 & 4 & 2 & 2 & 1 \\
\hline
\end{tabular}

hand, the results of Maltzaga-Zumarraga, Plazaola and Bilbao-Lezama railways show that they have fewer possibilities to assume different uses for the territorial structuring, leaving their future direction towards the use of their paths as territorial union.

The uniformity analysis of nodes/line relations, done by box-plot type graphs, shows that some railway lines need a division into zones for the achievement of more accurate results. For instance, in Urola railway, two adjacent outliers are obtained, which represent the division of the system into two zones. In Irati and Bidasoa railways, some of its nodes have disappeared by zones, so some outliers far from the remaining values appear, creating different zones, two in Irati and three in Bidasoa. Finally, in Vasco-Navarro railway, the obtained outliers are scattered and the division is not so clear, so a partition that fits the territorial distribution has been made (five zones). The results of the comprehensive analysis on the divided zones could be observed in the right part of Table 2. The results of the division show that, Irati and Bidasoa railways present a zone where the results are worse than the ones obtained before the division. It means that the division is adequate to understand the system in these two railways. However, in the Urola railway case the division adds nothing new to the analysis. Finally, although there is a zone with different results, the proposed division in Vasco-Navarro railway is not clarifying, probably due to an excessive fragmentation.

\subsection{PCA and k-mean classification of DRLs}

The PCA analysis has been applied in the eight whole lines and the 12 zones of the four divided lines. The correlation matrix shown in Table 3 reveals that the preservation of nodes (B) is intercorrelated with the relation between the line and the nodes (C), while the latter is also correlated with the relation between the nodes and the territory (E). Meanwhile, the relation between line and territory (D) and the relation between the whole system and the territory (F) are not correlated with any other variables.

The first three components account for the $84.5 \%$ of the total variance, with a variance of up to $18 \%$, while eigenvalues fall less than unity after the first two components, Table 3. 
Table 3: Correlation matrix of the PCA (left). The values in bold represent significant correlations (95\%). Component characteristics of the PCA (right). The values in bold are meaningful.

\begin{tabular}{|c|c|c|c|c|c|c|c|c|c|c|}
\hline & B & $\mathrm{C}$ & $\mathrm{D}$ & $\mathrm{E}$ & Component & $\mathrm{F} 1$ & $\mathrm{~F} 2$ & F3 & F4 & F5 \\
\hline B & 1 & & & & Eigenvalues & 2.196 & 1.126 & 0.903 & 0.570 & 0.204 \\
\hline $\mathrm{C}$ & 0.573 & 1 & & & Variance $(\%)$ & 43.924 & 22.529 & 18.051 & 11.406 & 4.090 \\
\hline D & -0.253 & 0.000 & 1 & & $\%$ cumulated & 43.924 & 66.453 & 84.504 & 95.910 & 100.000 \\
\hline $\mathrm{E}$ & 0.297 & 0.600 & -0.285 & 1 & & & & & & \\
\hline $\mathrm{F}$ & 0.006 & 0.363 & 0.000 & 0.2891 & & & & & & \\
\hline
\end{tabular}

These three components are presented in Fig. 7. On the one hand, the first component or factor $(\mathrm{F} 1)$ has a variance of $43.92 \%$ and is determined by the items related to the nodes $(\mathrm{B}, \mathrm{C}$ and E), as expected in the correlation matrix. On the other hand, the factor F2 (22.53\%) is characterized by line/territory (D) and system/territory (F) relations. Finally, the third factor F3 $(18.05 \%)$ sets the line/territory (D) relations and, to a lesser extent, the preservation of the nodes (B) against the system/territory (F) relations. In this regard, the two first components are able to represent all the variables easily. The 20 DRLs are represented depending on the new principal components, Fig. 7.

The k-mean classification has implemented the coordinates of the first three principal components and DRLs have been distributed into three groups, Table 4. Seven elements have been classified in group 1, and nine in group 2. Four of the latter are part of the same disused line (Vasco-Navarro), which has its most unfavourable zone in group 1. Urola and two sections of the Bidasoa railway comprise the third group.

The three groups show similar coordinates for the third component, so they are mainly characterized by the first two, Table 5. K-mean classification has also been made for these two components and only one of the DRLs has a change of group (Bilbao-Lezama is located in group 1), since it results are related to a single node. Group 1 is characterized by low node potential but presents better results in relation to the line characteristics and the territorial axis that are located around it. That is why the future of these DRLs should be related to the transportation connections that the line could create, and uses such as greenways could be
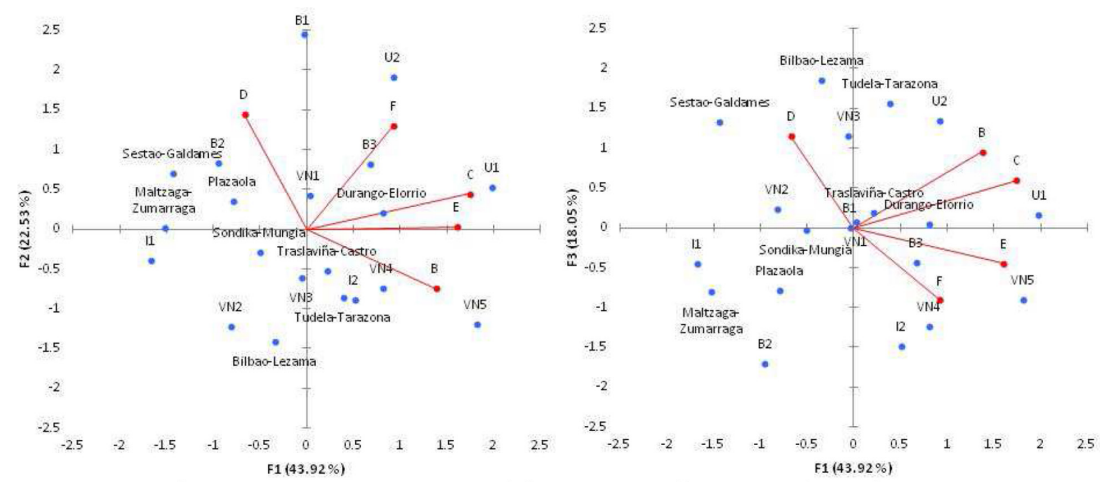

Figure 7: PCA components and the corresponding new values of DRLs. 
Table 4: DRLs of each group.

\begin{tabular}{lll}
\hline Group 1 & Group 2 & Group 3 \\
\hline Maltzaga-Zumarraga Plazaola & Durango-Elorrio Tudela-Tarazona & Urola (1) Urola (2) \\
Sondika-Mungia Bidasoa (2) & Traslaviña-Castro Bilbao-Lezama & Bidasoa (1) Bidasoa (3) \\
Vasco-Navarro (2) Irati (1) & Vasco-Navarro (1) Vasco-Navarro (3) \\
Sestao-Galdames & Vasco-Navarro (4) Vasco-Navarro (5) \\
& Irati (2) & \\
\hline
\end{tabular}

Table 5: Characteristics and centroids (F1, F2, F3) of groups. $\mathrm{N}$ is the number of DSRs per group.

\begin{tabular}{lccccl}
\hline Group & $\mathrm{N}$ & $\mathrm{F} 1$ & $\mathrm{~F} 2$ & $\mathrm{~F} 3$ & Observations \\
\hline 1 & 7 & -1.629 & -0.006 & -0.306 & $\begin{array}{l}\text { Low potential in relation to the nodes and } \\
\text { medium territorial potential }\end{array}$ \\
2 & 9 & 0.685 & -0.666 & 0.127 & $\begin{array}{l}\text { Medium/high potential of the nodes and } \\
\text { medium/low territorial potential }\end{array}$ \\
3 & 4 & 1.309 & 1.508 & 0.250 & $\begin{array}{l}\text { High potential of the nodes and high } \\
\text { territorial potential }\end{array}$ \\
\hline
\end{tabular}

appropriate. Although group 2 does not show so much potential in relation to the territorial scale, the characteristics of the nodes and their relations make possible the use of these DRLs for the development of the surrounding urban and rural areas, including the use of the line for connections at local level. Finally, group 3 has high potential in all areas, that is why these specific DRLs are the most suitable to take advantage to their territorial structuring capability, creating comprehensive proposals that are able to integrate the whole system including the enhancement of the nodes to the general proposal of the line.

\section{CONCLUSIONS}

Disused railway lines have been frequently studied from their opening to their closure from different points of view, such as economic, historical or urban development $[1,13,15,16]$. However, of the need for a comprehensive analysis of their historical and current situation is identified in order to develop future possible strategies to their maintenance and enhancement.

This paper creates a comprehensive analysis method and a GIS-based inventory for the characterization and classification of disused railway lines, understanding them as complex systems. A division of the study on the elements as themselves and on their relations is proposed, comprehending thus each railway element as part of the whole railway system. In this way, the surrounding territory is also taken into account, which permits a more extensive study of the disused lines. In this regard, the territorial structuring potential of the DRS is shown, in order to cover new uses beyond the current greenways while promoting the preservation of this heritage. Furthermore, the historical performance of the railway as a system and its integration into that period's territory are considered in addition to the current data. They 
are essential for the creation of future strategies to take advantage of the structuring character they had in the past, which is one of the most important features for their possible reuse in the new territorial view of the 21st century. In this regard, although several elements have already disappeared, items such as heritage traces or collective memory are related to the historical analysis. A GIS-based inventory is used, permitting an easy storage, management and updating of data referred to the different periods. In this way, the continuously updated current state of the elements is provided, which is necessary due to the continuous damage and disappearance of the heritage elements of the system. Although the inventory provides a lot of information referred to the system elements, it is not able to provide information about the created relations. However, it is possible to appreciate some differences between lines and zones in the created maps and conclude some of the reasons, such as the long period between their closure years or the existence of big or dense cities that could have urban development pressures.

The methodology has been applied to a real case, where the disused railways from the Basque Country and Navarre have been studied in depth. However, any other territory with several disused lines could be also analyzed by means of the comprehensive method. The application is based on the analysis of a system composed by a linear component (the line) and some point components (the nodes). That is way the presented method could be widespread to other territorial linear systems such as rivers and their hydroelectric plants or cattle routes.

In this case, the results of the characterization have already shown the high potential of the Urola line or the low potential of the Maltzaga-Zumarraga line, which are confirmed in the PCA and k-mean analyses. However, it is more difficult to read the results especially in the cases where the results of the different areas have variations between them. In this regard, the PCA analysis has shown the relations between the different analysis areas creating new components, while the k-mean classification has provided a suitable grouping of the lines. The three groups characterized by only two main factors have permitted to identify future approaches that each line could have for its preservation and enhancement. Group 3 is the most unfavourable, so it will be difficult to create new uses beyond the greenways. Meanwhile, in group 2 and especially in group 3 new uses that combine the different elements of the system should be proposed, where the preservation of the heritage elements should be ensured. K-mean classification has also confirmed the necessary division into zones of some of the lines. Previously identified unfavourable sections of Irati and Bidasoa railways are located in group 1, while other sections are located in group 2 (Irati) or group 3 (Bidasoa). In the case of Urola, both sections are located in the same group, claiming that there is no necessity for that division.

To conclude, the comprehensive analysis has been limited to less quantity and more selected information since the analysis of different systems requires data that must be comparable in order to create a classification between them. That is why the inventory and the comprehensive analysis should be detailed according to the selected analysis scale. Meanwhile, the characterization obtained from the analysis of each DRS results is inaccurate, requiring a more detailed and specific study as a multilevel approach with more information in each of the areas.

\section{ACKNOWLEDGEMENTS}

This research was supported by a research training grant from the Department of Education, Language policy and Culture of the Basque Government. The useful comments of the two anonymous reviewers are also gratefully acknowledged. 


\section{REFERENCES}

[1] Aguilar, I., La estación de ferrocarril puerta de la ciudad, Generalitat Valenciana: Valencia, 1988.

[2] Aguilar, I., La investigación sobre el Patrimonio Industrial. Una revisión bibliográfica. TST Transportes, Servicios y Telecomunicaciones, 1, pp. 169-186, 2001.

[3] García, Abased Patrimonio Ferroviario Aragonés. Propuesta para una red de museos especializados. Jornadas Patrimonio Industrial y Obra Pública, eds. Gobierno de Aragón, Departamento de Educación, Cultura y Deporte Zaragoza, 2007.

[4] Porcal, M.C., El patrimonio rural como recurso turístico. La puesta en valor turístico de infraestructuras territoriales (rutas y caminos) en las áreas de montaña del País Vasco y de Navarra. Cuaderno de Turismo. Universidad de Murcia, 27, pp. 759-784, 2011.

[5] Ferrari, M., Paisaje y patrimonio en la línea ferroviaria 'Jujuy-La Quiaca'. Una propuesta de reutilización para el desarrollo local. Labor \& Engenho L \& E, 6(1), pp. 89-108, 2012.

[6] UNESCO, Directrices Prácticas para la aplicación de la Convención del Patrimonio Mundial, Centro de Patrimonio Mundial de la UNESCO: Paris, 2008.

[7] ICOMOS, Carta de Itinerarios Culturales, $16^{\mathrm{a}}$ Asamblea General del ICOMOS: Québec, 2008.

[8] Gobierno Vasco, Inventario de Paisajes Industriales en el Ámbito de la Comunidad Autónoma del País Vasco, Departamento de Educación, Política Lingüística y Cultura, 2013.

[9] España, Ley Foral 14/2005, de 22 de noviembre, del Patrimonio Cultural de Navarra, B.O. de Navarra, 25 de noviembre de 2005.

[10] Eizaguirre-Iribar, A., Etxepare, L. \& Hernández-Minguillón, R.J., An approach to a methodology for the analysis and characterization of disused railway lines as a complex system. WIT Transactions on the Built Environment, 153, pp. 811-823, 2015. http://dx.doi.org/10.2495/STR150671

[11] Llano-Castresana, U., Azkarate, A. \& Sánchez-Beitia, S., The value of railway heritage for community development. WIT Transactions on the Built Environment, 131, pp. 61-72, 2013. http://dx.doi.org/10.2495/STR130061

[12] Montaner, J.M., Sistemas arquitectónicos contemporáneos, Gustavo Gili: Barcelona, 2008.

[13] González, M., Urrutikoetxea, J. \& Zárraga, K., Ferrocarril y capital humano. Dos eslabones fundamentales en el proceso vasco de modernización (1877-1930). VI Congreso de Historia Ferroviaria, Vitoria-Gasteiz, 2012.

[14] FFE, Inventario de las líneas ferroviarias en desuso, Fundación de Ferrocarriles Españoles, 1993.

[15] Macías, O., Ferrocarriles y desarrollo económico en el País Vasco (1914-1936), Universidad del País Vasco. Facultad de Ciencias Sociales y de la Información, Departamento de Historia Contemporanea: Leioa, 1994.

[16] Olaizola, J., \& Vaillant, C.G., Historia del ferrocarril en el País Vasco: siglo XX, Etor-Ostoa: Lasarte-Oria, 2011. 